\section{Work in Progress}

\section{Development of an Automated 3D Segmentation Program for Volume Quantification of Body Fat Distribution Using CT}

\author{
Shunsuke Ohshima, Shuji Yamamoto, ${ }^{1)}$ Taiki Yamaji, ${ }^{2)}$ Masahiro Suzuki, ${ }^{1}$ \\ Michihiro Mutoh, ${ }^{3)}$ Motoki Iwasaki, ${ }^{2)}$ Shizuka Sasazuki, ${ }^{2)}$ \\ Ken Kotera, Shoichiro Tsugane, ${ }^{2)}$ Yukio Muramatsu, ${ }^{1)}$ \\ and Noriyuki Moriyama ${ }^{1)}$ \\ Fujifilm Medical Co., Ltd. \\ 1 ) National Cancer Center: Tsukiji Campus, Research Center for Cancer Prevention and \\ Screening, Cancer Screening Division (3rd Term Comprehensive 10-Year Strategy for \\ Cancer Control.) \\ 2) National Cancer Center: Tsukiji Campus, Research Center for Cancer Prevention and \\ Screening, Epidemiology and Prevention Division \\ 3) Cancer Prevention Basic Research Project, National Cancer Center Research Institute
}

Received June 6, 2008

Revision accepted July 10, 2008

Code No. 251

\section{Introduction}

Recent interested in metabolic syndrome has spurred a great deal of research into the quantitative evaluation of body fat distribution using diagnostic imaging. People with metabolic syndrome are at increased risk of coronary heart disease and other diseases related to plaque buildup in the artery walls (e.g., stroke and peripheral vascular disease) and type II diabetes. ${ }^{1-3)}$ Abdominal obesity is one of several risk factors that, taken together, characterize metabolic syndrome. An excess of visceral fat leads to not only the "pot belly" or "beer belly" effect but also to vascular inflammation. ${ }^{4)}$ To quantify the distribution of body fat, various methods employing automatic or semiautomatic segmentation of both subcutaneous fat and visceral fat have been introduced. ${ }^{5-7)}$ Typical studies estimate the area of visceral fat on a single slice located at the navel. ${ }^{8-10)}$ However, this single-slice quantifica- tion does not accurately measure the full distribution of subcutaneous fat or visceral fat in the entire abdominal field. It is well known that modern computed tomography (CT) scanners offer isotropic sub-millimeter resolution volumetric scans of the entire abdominal area with considerably shorter scan times. The purpose of this work is to develop a practical and efficient computer software tool to assist in the automated estimation of the three-dimensional (3D) distribution of the body fat on volumetric CT images.

\section{Materials and Methods}

\section{1-1 Data Acquisition}

This study included 32 patients who underwent multi-detector row CT (Aquillion 16, Toshiba Medical Systems Corp., Tochigi, Japan) scans of the abdomen. Informed consent was obtained from each subject, and the use of the clinical image data was approved by the

\title{
Summary
}

The objective of this study was to develop a computing tool for full-automatic segmentation of body fat distributions on volumetric CT images. We developed an algorithm to automatically identify the body perimeter and the inner contour that separates visceral fat from subcutaneous fat. Diaphragmatic surfaces can be extracted by model-based segmentation to match the bottom surface of the lung in CT images for determination of the upper limitation of the abdomen. The functions for quantitative evaluation of abdominal obesity or obesity-related metabolic syndrome were implemented with a prototype three-dimentional (3D) image processing workstation. The volumetric ratios of visceral fat to total fat and visceral fat to subcutaneous fat for each subject can be calculated. Additionally, color intensity mapping of subcutaneous areas and the visceral fat layer is quite obvious in understanding the risk of abdominal obesity with the 3D surface display. Preliminary results obtained have been useful in medical checkups and have contributed to improved efficiency in checking obesity throughout the whole range of the abdomen with 3D visualization and analysis.

Key words: automatic segmentation, fat distribution, $C T$

別刷資料請求先：干106-0031 東京都港区西麻布2-26-30

富士フイルムメディカル株式会社ＩTソリューション事業本部事業推進部大島俊介＼cjkstart宛 
Ethical Review Board. Whole abdominal scans were performed on healthy subjects who had medical checkups with $120 \mathrm{kV}$, variable tube-current with volume exposure control (EC) (noise level at standard deviation 30), 0.5 sec-rotation, $1 \times 16$ slice, and FOV $320 \mathrm{~mm}$. The analytical post-processing using shape- and appearancebased segmentation and fast-volume rendering was developed by Fujifilm Medical Co., Ltd., Tokyo, Japan. The post-processing algorithms were installed on a standard personal computer (PC) (central processing unit: Intel Corp. Pentium IV dual $3.00 \mathrm{GHz}$, memory: 2048 MB, graphics card: ATI Technologies Inc. Mobility Radeon 9700, and operating system: Windows XP).

\section{1-2 Method of Automatic Segmentation of Abdominal Fat}

In this work, the default intensity range of fat was chosen as -190 to -30 Hounsfield units (HU), a range consistent with previously published literature. ${ }^{11,12)}$ Visceral fat is defined as the intraperitoneal area with intensities in the fat range defined above, whereas subcutaneous fat is defined as the fat layer between the innermost surface of the skin and the outer margin of the abdominal wall musculature. We developed a fully automatic algorithm to identify the body perimeter and the inner contour that separates the visceral fat from the subcutaneous fat. Before running this algorithm, users must first manually set the range for the segmentation area between segment 8 of the liver (S8) and the symphysis pubica, the area on which the model is based. Figure 1 shows the flowchart of the algorithm. The algorithm starts by detecting the S8 segment of the liver. Next, to eliminate fat around the heart, an automated method is used to extract the diaphragm surface by deforming a thin-plate model to match the bottom surface of the lung. ${ }^{13-15)}$ The outer body contour for each slice was extracted using a simple threshold method together with morphological filtering. To extract the subcutaneous layer and visceral fat area on each CT slice, radii from two detected points are drawn at fixed 5 -degree increments towards the outer contour in all slices except those in the pelvis (Fig. 2a, b, and c). A single point located at the centroid of the extracted body perimeter is used in the slice containing the pelvic cavity. This was done to make a convergent point in the suprapubic region at a lowest slice level. Finally, the extracted subcutaneous layer and the visceral fat area in all slices were rendered as 3D data (Fig. 2d).

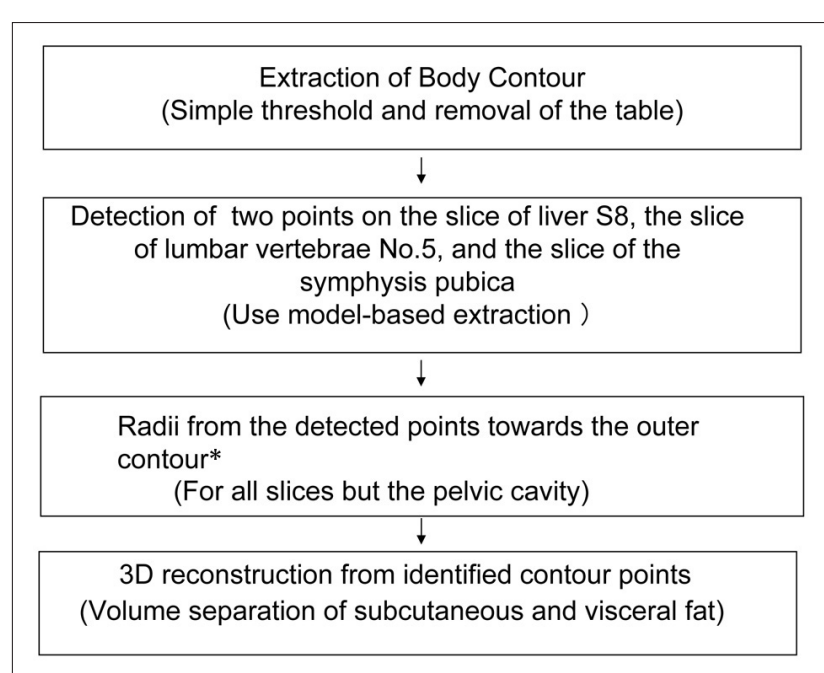

Fig. 1 Algorithm flowchart of automated segmentation of the body fat distribution.

*: On the symphysis pubica slice, draw radii from a single center point.

\section{1-3 Overview of software design}

To obtain the volume of both subcutaneous and visceral fat, the above-described algorithm is run automatically on the volume data set. The fat volumes are calculated using simple counting of the total number of pixels multiplied by the image resolutions in the $\mathrm{x}$ and $y$ directions in the fat region. In this work, the volume of interest was defined from the surface of the diaphragm to the coccyx. Should the automatically extracted contours be suboptimal, the system allows manual corrections. The volumetric ratios of visceral fat to total fat and visceral fat to subcutaneous fat for each of the patients can be calculated. The fat area on each slice level can be readily verified using the slider line on the slice number-fat area graph implemented in the software. The automatically extracted and manually edited inner and outer contours can be controlled by the user. The 3D surface rendering of the color intensity mapping of the subcutaneous layer and visceral fat area make it quite easy to understand the risk of abdominal obesity.

\section{Results and Discussion}

Figure 3 shows the orthogonal view of the extracted volume of subcutaneous and visceral fat as well as the extracted surface of the diaphragm. The results of the segmentation of the fat region were quantitatively estimated using graphs plotting the fat area of both subcutaneous and visceral fat for each slice level of the CT (Fig. 4). In this example case, the results of total fat 

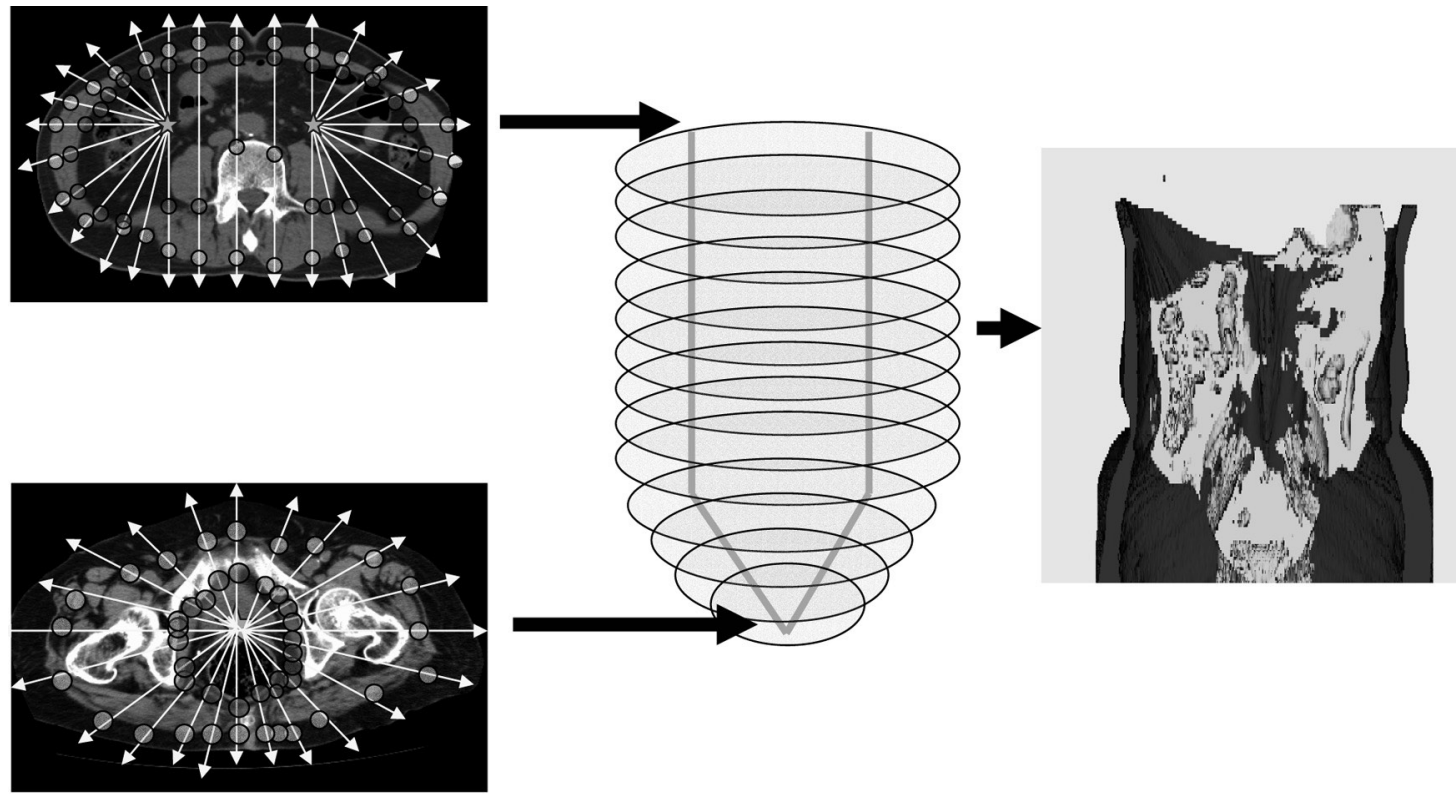

Fig. 2 Determination of subcutaneous fat layer and visceral fat area.

(a) Radii drawn from the two points towards outer contour at fixed angles.

(b) Radii drawn from the body center outer contour at the slice level of the pelvic cavity.

(c) Schematic representation of segmentation of subcutaneous fat layer and visceral fat area for each slice level.

(d) 3D display of extracted subcutaneous and visceral fat distribution using our developed algorithm.

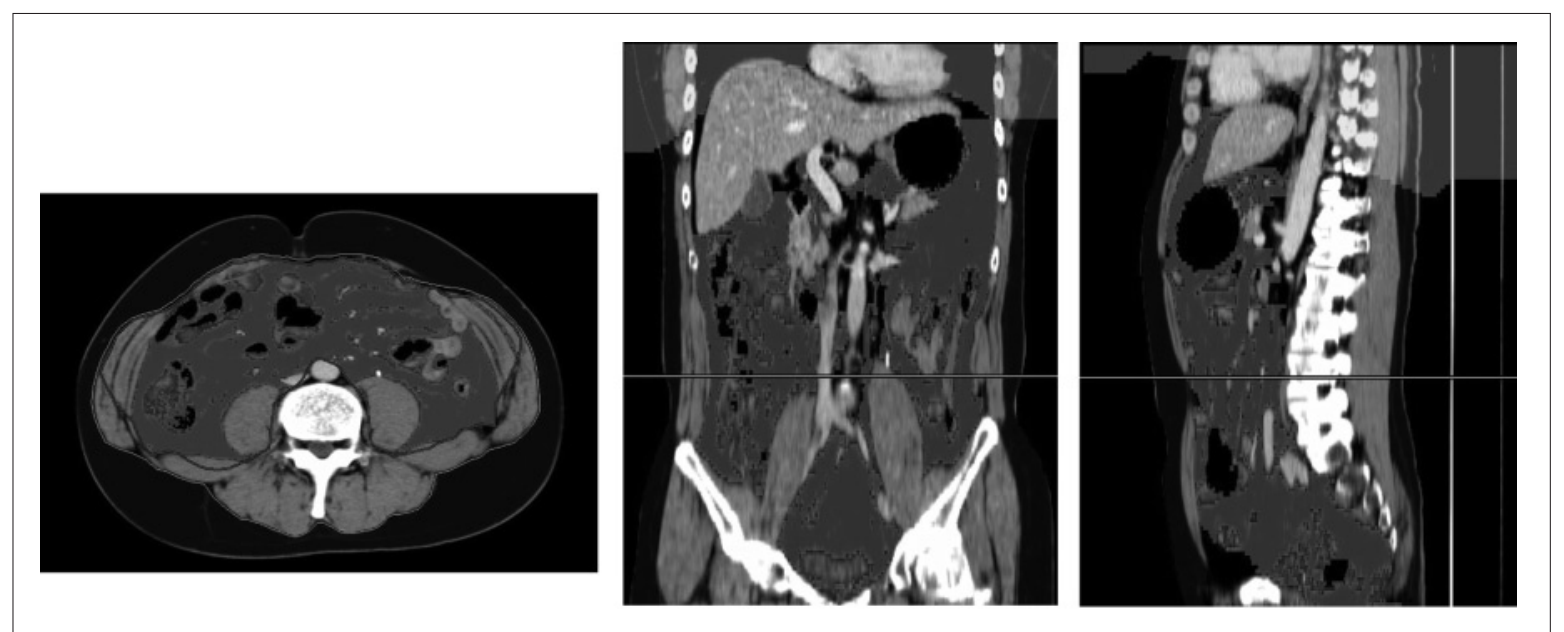

Fig. 3 Orthogonal reconstructed views of the extracted subcutaneous and visceral fat distribution with automated detection algorithm of the diaphragm surface.

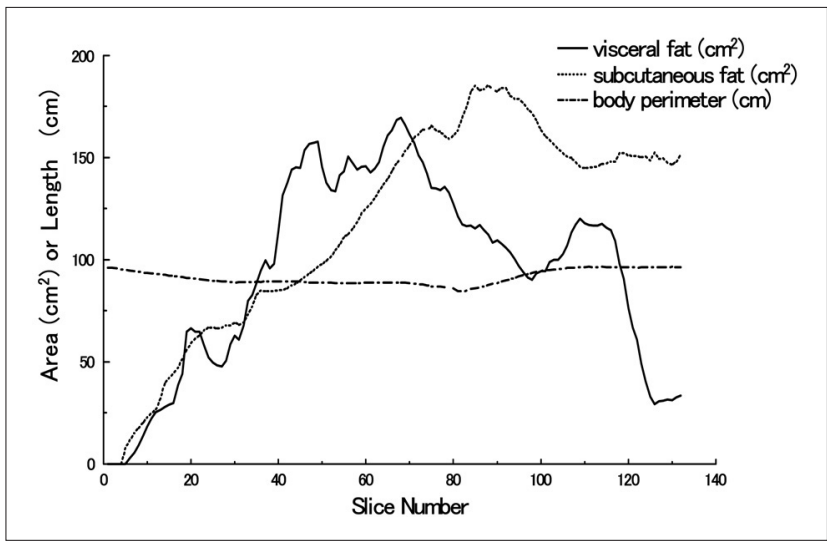

Fig. 4 An example analysis plotting three parameters related to abdominal obesity [change in subcutaneous fat area $\left(\mathrm{cm}^{2}\right)$, visceral fat area $\left(\mathrm{cm}^{2}\right)$, and body perimeter $(\mathrm{cm})$ ] for each slice position in the abdominal range. 


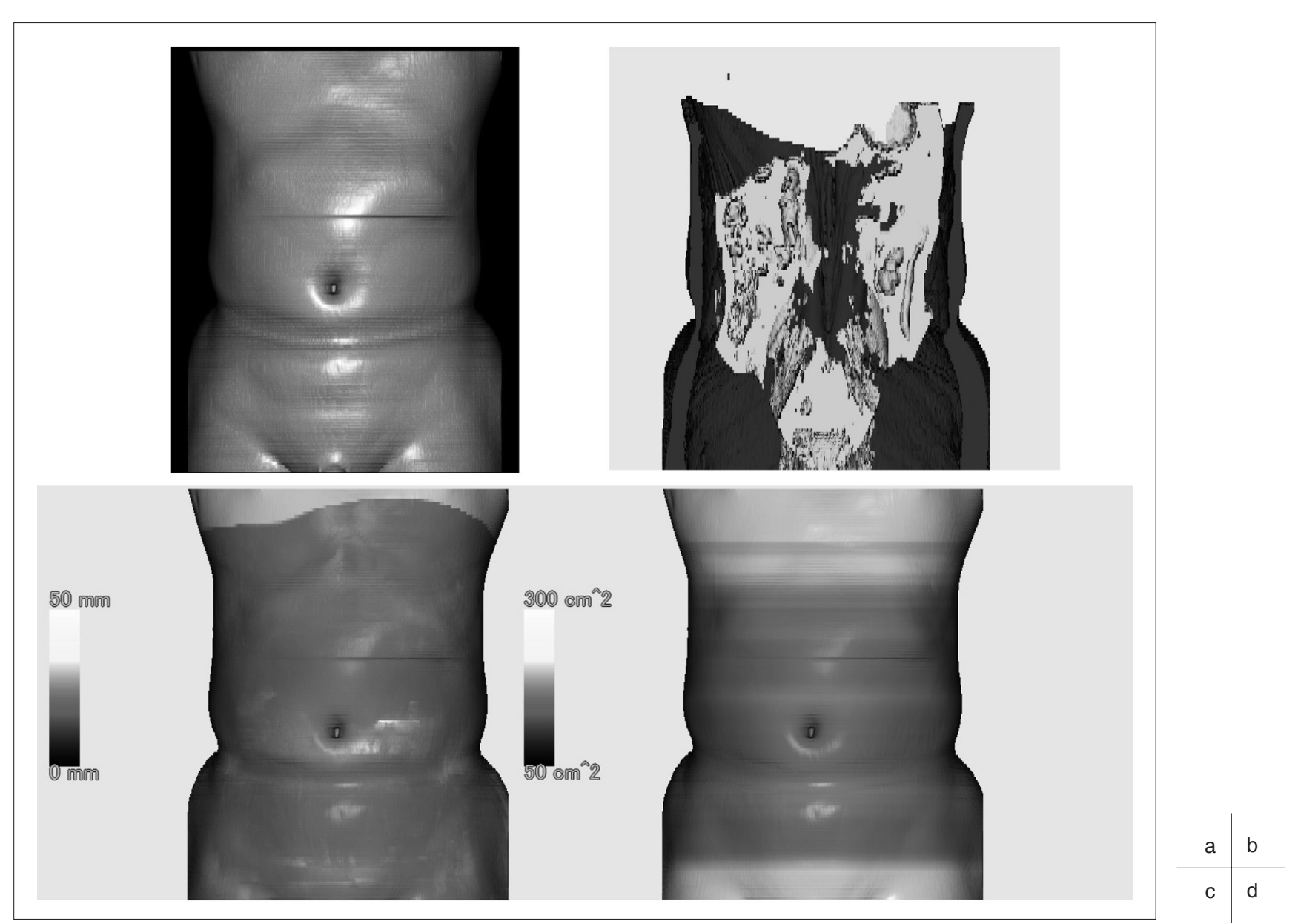

Fig. 5 Volume visualizations of fat distribution.

(a) Conventional skin surface display of entire abdomen.

(b) 3D display of the extracted volume of subcutaneous and visceral fat.

(c), (d) 3D color intensity mappings of subcutaneous fat and visceral fat, respectively.

volume, subcutaneous fat volume, and visceral fat volume were $10095 \mathrm{~cm}^{3}, 5575 \mathrm{~cm}^{3}$, and $4520 \mathrm{~cm}^{3}$, respectively. Further work is underway to compare the results of volumetric fat distribution with those of the conventional single-slice technique. Figure 5 shows the various $3 \mathrm{D}$ displays that can be used to visualize the fat distribution. The conventional whole abdomen skin surface is shown in Fig. 5a. A volume rendering of the extracted subcutaneous and visceral fat is shown in Fig. 5 b. Color intensity mapping of the subcutaneous layer and the visceral fat area for each slice are shown in Fig. $5 \mathrm{c}$ and $\mathrm{d}$, respectively. From these results, color texture mapping using quantified values of fat distribution makes it quite easy to understand the risk of abdominal obesity. One technical issue, however, is the problem of errors in contouring caused by rare anatomical cases.
This key issue remains to be clarified. The methods used in this work appear to be rather case specific, and possible extensions and applications of these methods to generic design cases will require further study.

\section{Conclusion}

In conclusion, we developed computing tools used to automatically quantify body fat distribution with efficient 3D visualization and analysis, providing insight into obesity-related metabolic syndrome.

\section{Acknowledgements}

This work was supported by the Foundation for Promotion of Cancer Research for 3rd Term Comprehensive 10-Year Strategy for Cancer Control. 


\section{Reference}

1) Vlek AL, van der Graaf $Y$, Spiering $W$, et al. Effect of metabolic syndrome or type II diabetes mellitus on the occurrence of recurrent vascular events in hypertensive patients. J Hum Hypertens 2008; 22 (5) : 358-365.

2) Hsu IR, Kim SP, Kabir M, et al. Metabolic syndrome, hyperinsulinemia, and cancer. Am J Clin Nutr 2007; 86 (3): s867-871.

3) Pradhan A. Obesity, metabolic syndrome, and type 2 diabetes: inflammatory basis of glucose metabolic disorders. Nutr Rev 2007; 65(12 Pt 2): S152-156.

4) Fontana L, Eagon JC, Trujillo ME, et al. Visceral fat adipokine secretion is associated with systemic inflammation in obese humans. Diabetes 2007; 56(4) : 1010-1013.

5) Zhao B, Colville J, Kalaigian J, et al. Automated quantification of body fat distribution on volumetric computed tomography. J Comput Assist Tomogr 2006; 30 (5): 777-783.

6) Brennan DD, Whelan PF, Robinson K, et al. Rapid automated measurement of body fat distribution from wholebody MRI. AJR Am J Roentgenol 2005; 185(2) : 418-423.

7) Kim S, Lee GH, Lee $S$, et al. Body fat measurement in computed tomography image. Biomed Sci Instrum 1999; 35: 303-308.

8) Katznelson L, Rosenthal DI, Rosol MS, et al. Using quantitative $\mathrm{CT}$ to assess adipose distribution in adult men with acquired hypogonadism. AJR Am J Roentgenol
1998; $170(2):$ 423-427.

9) Snehalatha C, Ramachandran A, Satyavani K, et al. Computed axial tomographic scan measurement of abdominal fat distribution and its correlation with anthropometry and insulin secretion in healthy Asian Indians. Metabolism 1997; 46(10) : 1220-1224.

10) Armellini F, Zamboni M, Robbi R, et al. Total and intraabdominal fat measurements by ultrasound and computerized tomography. Int J Obes Relat Metab Disord 1993; $17(4): 209-214$

11) van der Kooy K, Seidell JC. Techniques for the measurement of visceral fat: a practical guide. Int J Obes Relat Metab Disord 1993; 17(4); 187-196.

12) Yoshizumi $T$, Nakamura $T$, Yamane $M$, et al. Abdominal fat: standardized technique for measurement at CT. Radiology 1999; 211(1): 283-286.

13) Zhou X, Ninomiya H, Hara T, et al. Automated estimation of the upper surface of the diaphragm in 3-D CT images. IEEE Trans Biomed Eng 2008; 55(1) : 351-353.

14) Rangayyan RM, Vu RH, Boag GS. Automatic Delineation of the Diaphragm in Computed Tomographic Images. J Digit Imaging 2008 Jan 23 (online-publication) .

15) Reinhard B, Georg G, Erich S,et al. Diaphragm dome surface segmentation in CT data sets: a 3D active appearance model approach. Proc. SPIE 2002; 4684: 475-484.

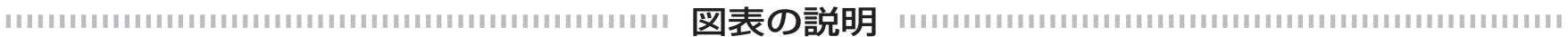

Fig. 1 体脂肪分布の自動領域抽出のためのアルゴリズムフローチャート

Fig. 2 皮下脂肪層と内臓脂肪エリアの決定
(a) スライス内の二つのポイントから体輪郭方向へ一定角度で半径の描画
(b) 恥骨上縁のスライスレベルで体軸中心から対輪郭方向へ半径の描画
(c) スライスごとの皮下脂肪層と内藏脂肪エリアの領域抽出のための説明図
(d) 本アルゴリズムを用いた皮下脂肪拉よび内臓脂肪分布の三次元表示

Fig. 3 モデルベースの横隔膜の自動領域抽出アルゴリズムを用いた皮下脂肪と内臓脂肪抽出後の垂直断面変換表示

Fig. 4 腹部肥満を特徵付けるパラメータを用いた解析事例

全腹部範囲のスライスごとの皮下脂肪面積 $\left(\mathrm{cm}^{2}\right)$, 内臓脂肪面積 $\left(\mathrm{cm}^{2}\right)$ および体周囲長 $(\mathrm{cm})$ の変化

Fig. 5 脂肪分布の定量的可視化によるさまざまな三次元表示例
(a) 腹部全体の慣習的な三次元表皮サーフェス表示
(b) 抽出された皮下脂肪と内臓脂肪の三次元表示
(c) 三次元サーフェス上の皮下脂肪層のカラー濃淡マッピング
(d) 三次元サーフェス上にスライスごとの内藏脂肪面積をカラー濃淡マッピングした例 